\title{
Legal Aspects of Micro Business Development Institutions in State Purpose of Welfare
}

\section{Lukmanul Hakim ${ }^{1}$, Etty Mulyati², Djuhaendah Hasan ${ }^{3}$, Tarsisius Murwadji ${ }^{4}$}

\author{
${ }^{1}$ Universitas Bandar Lampung, Indonesia, Email: lukmanul.hakim@ubl.ac.id \\ ${ }^{2}$ Universitas Padjadjaran,Indonesia, Email:etty.mulyati@unpad.ac.id \\ ${ }^{3}$ Universitas Padjadjaran, Indonesia, Email: djuhaendah.hasan@unpad.ac.id \\ ${ }^{4}$ Universitas Padjadjaran, Indonesia, Email:t.murwadji@unpad.ac.id
}

\begin{tabular}{|c|c|}
\hline Article Info & Abstract \\
\hline $\begin{array}{l}\text { Keywords: } \\
\text { Legal Aspects, Finance, and Micro } \\
\text { Business. } \\
\text { How to cite: } \\
\text { Lukmanul Hakim, Etty Mulyati, } \\
\text { Djuhaendah Hasan, } \\
\text { Tarsisius Murwadji, "Legal } \\
\text { Aspects of Micro Business } \\
\text { Development Institutions in State } \\
\text { Purpose of Welfare", Fiat Justisia: } \\
\text { Jurnal Ilmu Hukum 14, } 3 \text { (2020): } \\
247-260 . \\
\text { DOI: } \\
\text { 10.25041/fiatjustisia.v14no3.1804 }\end{array}$ & $\begin{array}{l}\text { Micro-business is one of the activities that is } \\
\text { currently almost 90\% the share of business in } \\
\text { Indonesia, considering the micro business is an } \\
\text { informal business, and not many micro-businesses } \\
\text { have been touched by the financing sector so that } \\
\text { micro-businesses are not affected in the economic } \\
\text { crisis. In addition, micro-businesses are } \\
\text { complicated to develop their businesses due to the } \\
\text { lack of requirements to get funding and guidance } \\
\text { that is still not effective, resulting in the lack of } \\
\text { information for businesses to take advantage of } \\
\text { existing market share. Moreover, micro-businesses } \\
\text { must also be able to adapt to continue and grow } \\
\text { amidst the current difficult conditions. The problems } \\
\text { in this study are } 1 \text {. Growth of Micro Businesses and } \\
\text { the Concept of Development and Funding amid } \\
\text { Technology-Based Business Competition } 2 \text {. Legal } \\
\text { Aspects of Micro-Business Development in the } \\
\text { Welfare State's Goals. Results of this Research As } \\
\text { the goal of the welfare state is one of them to improve } \\
\text { the social welfare of the community. Micro- } \\
\text { businesses participate in the purpose of the welfare } \\
\text { state because remembering micro business as one of } \\
\text { the fundamental pillars of driving the economy in } \\
\text { Indonesia. It is necessary to have an active role of } \\
\text { government and society to participate in building } \\
\text { micro-businesses to be more developed so that the } \\
\text { increase of the economy both in the region and } \\
\text { nationally. So that the government must be able to } \\
\text { facilitate businesses so that micro businesses can } \\
\text { develop as the objectives of the welfare state. }\end{array}$ \\
\hline
\end{tabular}

\section{A. Introduction}


The performance of the Indonesian economy between 1998 and 2008 experienced a decline due to the current crisis at that time. Where some large businesses are unable to adapt, many are unable to survive. They cannot develop enterprises too because some business sectors that were ultimately affected by the crisis are no longer able to carry out their business activities in that year many large companies which one by one began to diminish due to the storm crisis. ${ }^{1}$

Microbusinesses in the informal sector can survive and adapt in business activities that are being hit by the economic crisis at that time because micro businesses do not get funds from financial institutions but still use private capital so that micro-businesses are not touched by banking institutions and do not cause micro-businesses to decline in performance. This makes the paradigm that micro-business is part of the business incubator that makes business embryos grow.

In this case, the government has a particular policy, especially regarding the development of micro-businesses in the future. Based on the experience of the crisis which leaves a story that the conditions of meaning given that the development of large-scale businesses is not appropriate, especially in improving social welfare and the purpose of improving the economy for the purpose of the welfare state. Whereas at present, the basic pillars of the business' economy come mostly from micro aspects such as labourers, retail traders, small craftsmen and farmers, who are facing funding problems.

Based on the experience of the monetary crisis in the 90s era, it provided input for the government's active roles in the development micro businesses that were initially informal to formal, because the level of flexibility of microbusinesses that were very dynamic and able to deal with the times resulted in micro-businesses having to be able to face difficult situations in the technological era currently.

Given the current era of digital technology, there are no more opportunities that are only owned by large-scale businesses. Still, with the role of digital technology at this time, it opens new opportunities for microbusinesses to expand the business. By increasing sales through a technology base using applications and advertisements on other online media, microbusiness has an important role, especially in economic development and employment, given the number of human resources which are still loweducated who are members of micro-businesses, which requires microbusinesses to improve themselves and be able to be technology literate. Microbusinesses in the traditional and modern sectors did not lag behind,

\footnotetext{
${ }^{1}$ Ihwan Susila, “Analisis Efisiensi UMKM,” Jurnal Ekonomi Pembangunan 8, No. 2 (2007): $167-168$
} 
especially in the millennial era where the development of micro-businesses that developed significantly.

In the context of developing micro-businesses in the technological era, the role of supporting applications also provides the same opportunities not only for large or medium-sized businesses but also provides opportunities for micro-businesses in the marketing sector of products that have been produced by micro-businesses in collaboration with several market places and ECommerce such as BukaLapak, Shopee, TokoPedia, Blibli.com and others in the product marketing sector that has been produced.

In addition, the role of other applications such as Go-Jek and Grab in transportation facilities and delivery provides easy access for microbusinesses in distribution that have been produced directly to consumers. Therefore, micro businesses do not have any difficulties in terms of delivering goods produced because there is already an application base that helps business operations.

The Growth of business climate based on juridical aspects can be found in Article 7 paragraph (1) UMKM Law stating: "The government and regional governments foster a business climate by stipulating laws and policies that include aspects: funding and institutional support".

Microbusiness as an effort to maintain the stability of the basic pillars of the Indonesian economy that contribute is critical, especially in economic development, ${ }^{2}$ as the goal of the welfare state which is fair and equitable towards welfare. ${ }^{3}$ The role of State in business development in facilitating funding or fostering business in micro-enterprises is very significant given the absorption of labour, as well as an increase in income from micro-businesses which indirectly contribute to economic growth and employment. Based on the background above, the issues to be discussed in this study are Legal aspects of micro business development institutions in the goal of the welfare state.

The research approach of this research is to use normative juridical to examine the rule, norms and directives related main objectives of this study. The literature review is needed to collect various laws, theories, and practices that are closely related to the problem to be examined. The data used in this study include secondary data, namely: data obtained from literature studies (literature studies).

\footnotetext{
${ }^{2}$ I.E. Thalassinos, and K. Liapis, Segmental Financial Reporting and the Internationalization of the Banking Sector, Chapter Book (Risk Management: Strategies for Economic Development and Challenges in the Financial System: (eds), D. Milos Sprcic, Nova Publishers, 2015),14.

${ }^{3}$ I. E. Thalassinos, D.T.Stamatopoulos, and E. P. Thalassinos, The European Sovereign Debt Crisis and the Role of Credit Swaps. Chapter book W. T. Ziemba and A.G. Malliaris,"The WSPC Handbook of Futures Markets" (eds), in memory of Late Milton Miller (Nobel 1990) World Scientific Handbook in Financial Economic Series5, No. 20 (2015): 605-639, doi:10.1142/9789814566926_0020.
} 
This data is obtained by studying, reading, quoting, analyzing literature, principles and theories of laws and regulations relating to the research subject. ${ }^{4}$

To complete the data to find the results of this study, the use of secondary data collection procedures carried out by conducting a literature study (library research) is needed. A literature study has the aim to get the direction of thought and research objectives through reading, quoting, and analyzing literature that supports the law as well as reading material and other scientificrelated issues to be discussed.

All data, both the literature or field of study, are then analyzed with a qualitative juridical analysis that illustrates the problem based on research and discussion in the form of explanations or descriptions arranged systematically. Conclusions are drawn to answer the research problem.

\section{A. Discussion}

\section{Micro Business Growth and the Concept of Development and Funding Amidst Technology-Based Business Competition}

The growth of micro-businesses in Southeast Asia currently reaches almost $89 \%$ majority, especially in some other developed countries that have microbusinesses ranging from $92 \%$ such as Indonesia, some countries' numbers of micro-businesses cover around 97\%, such as Singapore, Malaysia and Vietnam. Utilization of human resources is mostly absorbed by microbusinesses approximately 98 million in Indonesia, which provides the most considerable contribution in Southeast Asia in particular. Microbusiness products that have been exported are the smallest in the figure of $15.4 \%$ where the numbers do not meet the current needs.

The Free Market Era has entered the scope of trade in all countries in the world, but with the opening of the free market, it has made it difficult for micro-businesses to enter the export market share. ${ }^{5}$ Supporting facilities that need to be facilitated by the Government's need to increase the capacity of the micro-business itself, ${ }^{6}$ and foster a level of business competition with a healthy climate. ${ }^{7}$ The low level of achievement of micro-businesses which is

\footnotetext{
${ }^{4}$ Mukti Fajar dan Yulianto Achmad, Dualisme Penelitian Hukum Normatif dan Empiris, (Yogyakarta: Pustaka Pelajar, 2010), 156-158.

${ }^{5}$ Kiran V, Majumdar M, Kishore K, "Innovative Marketing Strategies for Micro, Small and Medium Enterprises", Interdisiplinary Journal of Contemporary Research in Business 4, No. 2 (2012): 1059-1066.

${ }^{6}$ Munizu M, "Pengaruh Faktor-Faktor Eksternal dan Internal Terhadap Kinerja Usaha Mikro dan Kecil (UMK) di Sulawesi Selatan",Jurnal Manajemendan Kewirausahaan 12, No. 1 (2010): 33-41.

${ }^{7}$ R. M. Aldaba, "SME development: narrowing the development gap in the ASEAN Economic Community", Philippine Journal of Development 39, No. 71 (2012): 143-169.
} 
one of the main causes of the lack of availability of market information, technological development, besides the tendency towards the government in assisting is still the most significant desire. ${ }^{8}$

Efforts to reduce social inequality to actively increase the level of community welfare by reducing existing problems so that the results can be enjoyed by the community and micro-businesses, one way that can be done is to empower cooperatives as alternative financing. The presence of cooperatives is one of the manifestations of the business economy in Indonesia. Cooperatives are part of business entities, and legal entities are a form of structured institutional structure model with the existence of an organizational body in accordance with the principle of kinship in the mandate of Article 33 of the 1945 Constitution. ${ }^{9}$ Cooperatives in this regard have been established in Indonesia through a legal umbrella in Cooperatives Law.

The birth of legal instruments that have been issued by the government as a support for capacity and competitiveness increase in micro-businesses, but the existing policies seem to be carried out late by the government because they have been implemented in the era of ASEAN Economic Community in the age of developing technology has taken place and many of part of the business, especially micro-businesses that are experiencing competitiveness inability, in the case of competition for micro-businesses, a classic problem that will soon be resolved by policymakers, especially in improving social welfare in the economic field. ${ }^{10}$

The right concept in coaching and funding for micro-businesses amid business competition and technological development can be realized by developing a Quadruple of Helix theory as a management system through an institutional system in increasing the capacity of micro-businesses so that micro businesses can develop better, in the regions usually has autonomy as well as accountability for regional development in accordance with the level of resources owned by each region.

Development strategic management planning based on rules that innovate, because through innovation tends to be known as a wheel of economic growth in an area. The concept in Quadruple Helix is one of the models of innovation that emphasizes the existence of cooperation between several related elements that are mutually integrated, including mechanisms from the government as

${ }^{8}$ IDKR, Ardiana. Brahmayanti IA, Subaedi,“Kompetensi SDM UKM dan Pengaruhnya Terhadap Kinerja UKM di Surabaya", Jurnal Manajemen dan Kewirausahaan 12, No. 1 (2010): 42-55.

9 Tarsisius Murwadji, "Edukasi dan Penyehatan Koperasi Melalui Linkage Program Perbankan”, PADJADJARAN Jurnal Ilmu Hukum 4, No. 3 (2017): 178, 2017), https://doi.org/10.22304/pjih.v4n3.a2.

${ }^{10}$ Muh. Risnain, Aspek-Aspek Hukum Peningkatan Daya Saing Industri Dalam Perdagangan Bebas (Bandung: Keni Media, 2015): 87. 
public policymakers; financial institutions that provide funding accordance to mandate of Micro, Small and Medium Business regulations, assistance of the role of academics in universities as policymakers and analysis of existing policies; credit guarantee institutions to provide legal certainty for microbusinesses that need funding in developing business activities provide a guarantee for micro businesses that do not have a guarantee which is a key requirement and the community/micro business people as users will be increased their capacity towards business development.

Some related parties will be together in harmony and form a coordinated helix towards the direction of development both in the region and at the centre. The concept of micro business development through Quadruple Helix can be used as a new reference for central and regional governments with the cooperation that is being combined with adjusting the conditions of the regions in each place.

The domestic market is seen as a policy framework or model for implementing strategic management in the long-term development of starting the process of learning based on innovation, change and improvement in the system. ${ }^{11}$ Moulaert \& Sekia uses the concept of territorial innovation model as a generic name for regional innovation model where the dynamics of local institutions especially local governments that have an important role new policy-making sector which plays an important role. So that with the new policy innovations both coming from the government and regional governments can synergize is expected to be able to answer the challenges for micro-businesses in the current global economic competition and trade liberalism of course. ${ }^{12}$

The concept of being an innovation development system can be understood both in the narrow and broad sense. ${ }^{13}$ A narrow understanding of the system of innovation by the method of combining research and development functions at universities managed by researchers and academics in each of these institutions, research institutions or even large companies, which reflects the top-down innovation model. As for the broad conception through the work system, the innovation method is more interactive and top bottom-up, especially in the economic sector and related institutional arrangements that

11 B. Asheim, "Differentiated Knowledge Bases and Varieties of Regional Innovation Systems", The European Journal of Social Sciences 20, No. 3 (2007): 223-241, https://doi.org/10.1080/13511610701722846.

${ }^{12}$ F. Moulaert, \& F. Sekia, "Territorial Innovation Models: A Critical Survey", Regional Studies 37, No. 3 (2002): 289-302, https://doi.org/10.1080/0034340032000065442.

${ }^{13}$ T. Piirainen, \& P. Koski, “Integrating Workplace Development Policy and Innovation Policy. A Challenging Task Experiences from the Finnish Workplace Development Program", pada Fricke, Werner and Totterdill, Peter (eds) Action Research in Workplace Innovation and Regional Development (Amsterdam: John Benjamins, 2004): 313-331. 
also influence the learning process, and assessment. ${ }^{14}$ The systems approach to innovation also emphasizes the principle of prudence in carrying out activities and developing policies in the public sector for innovation. ${ }^{15}$ (Both are the same sentence with different sources).

The systems approach to innovation also emphasizes the principle of prudence in carrying out activities and developing policies in the public sector for innovation. ${ }^{16}$ The previous discussion, Quadruple Helix united several institutional sectors respectively, both regional scale, and operations in sector lines in the economic context, the law regarding the rules that will provide legal certainty and knowledge for micro-businesses. The context provides an appropriate operational framework for embedding concepts in policies and practices, specifically in efforts to increase the capacity of micro-businesses. Carayannis et al. said the Quadruple Helix theory could thus function simultaneously involving the roles of the government, academics at universities, financial institutions, as well as credit guarantee institutions and of course, micro-businesses. Concept collaboration, design, implementation and development of the entrepreneurship sector and sustainable innovation, and encourage the growth of ecosystems (and other groups, networks and agglomeration) at the regional level. ${ }^{17}$

Capacity building for micro-businesses is currently the most important thing, especially in the current global economic competition and trade liberalization because it is the most important thing, especially with the application of the quadruple helix theory, of course, it is expected to be a good role going forward for the development of micro-businesses that are minimal guidance and funding not only in the macro segment but also in the microsegment remains reliable.

The importance of implementing quadruple helix is an obligation undertaken by stakeholders to advance business development institutions as a medium for micro-businesses. It is expected that with the existence of these business development institutions, all information available on microbusinesses will become one. There will be no more gaps or even a lack of data between one business and the other so micro-business information, in

\footnotetext{
${ }^{14}$ B. A. Lundvall, National Systems of Innovation. Towards a Theory of Innovation and Interactive Learning (London: Pinter Publishers, 1992), 271.

${ }^{15}$ C. Edquist, \& L. Hommen, "Systems of Innovation: Theory and Policy for the Demand Side",Technology in Society, 21 (1999): 63-79.

${ }^{16}$ E. Wise, \& C. Høgenhaven, User-Driven Innovation. Contex and Cases in the Nordic Region,(Nordic Innovation Centre, 2008), 28.

${ }^{17}$ E. G. Carayannis, R. J. Rakhmatullin, "The Quadruple/Quintuple Innovation Helixes and Smart Specialisation Strategies for Sustainable and Inclusive Growth in Europe and Beyond," Journal of Knowledge Economy 5, 2 (2014):212-239, https://doi.org/10.1007/s13132-0140185-8.
} 
particular, will no longer experience difficulties. Micro-businesses can become more It is effective because in this institution it becomes a unit, namely the existence of a form of providing training and training programs, an appropriate form of funding program carried out by the government and other private parties, as well as the concept of developing new information so that micro businesses do not lag behind the latest information.

\section{Legal Aspects of Micro Business Development in the Welfare State's Objectives}

Microbusiness development is needed to deal with other competitors both locally and domestically to foreign countries so that micro-businesses in Indonesia can compete with other businesses around the world by prioritizing the quality of products that will or have been produced.

But legally, it has been stipulated in Micro, Small and Medium Business' regulations regarding coaching and funding that needs to be facilitated by the government, in this case, the government provides coaching facilities through existing programs as well as funding through People's Business Credit distribution programs or Non-People's Business Credit.

The main problems in the development of micro-businesses can be seen so far in funding that is still not optimal and the lack of financial or nonfinancial institutions that look at micro-businesses due to the lack of requirements contained in micro-businesses so that in funding requests so far there has often been a rejection of micro-businesses. Banking institutions in order to minimize the risk of bad credit, considering that micro businesses are still categorized as high risk, is one reason for financial institutions to be able to finance micro businesses.

Credit analysis carried out by financial institutions usually applies the 6 C's principles, such as character, capacity, collateral, capital, condition and constraint. The primary purpose of the loan application analysis is to obtain confidence whether the customer has the will and ability to fulfil his obligations to the bank in an orderly manner, both the principal and interest payments, in accordance with the agreement with the bank. The things that need to be considered in settlement of customer credit; must first fulfil the Principle 6 C's Analysis, namely as: ${ }^{18}$

\section{a. Character}

Character is the character of the customer, both in personal life and in the business environment. The purpose of this character assessment is to find out the extent of the customer's willingness to fulfil their obligations (willingness

\footnotetext{
${ }^{18}$ Lukmanul Hakim dan Eka Travilta, "Prinsip Kehati-hatian Pada Lembaga Perbankan dalam Pemberian Kredit," Jurnal Keadilan Progresif 9, No. 2 (2018): 170.
} 
to pay) in accordance with the agreed agreement. As a tool to get a picture of the character of the prospective customer, can be achieved through efforts, among others:

1) Examining the life history of prospective customers;

2) Examining the reputation of the prospective customer in his business environment;

3) Request bank to bank information (Debtor Information System);

4) Looking for information to business associations where prospective customers are located;

5) Looking for information on whether prospective customers like to gamble;

6) Looking for information on whether prospective customers have a hobby of spree.

b. Capital

Capital is the amount of funds/own capital owned by prospective customers. The greater the equity capital in the company, of course, the higher the potential of the seriousness of prospective customers in running their business and the bank will feel more confident in providing credit. Banks also need their capital as a means of seriousness and responsibility of customers in conducting their business because they carry the risk of failure of the business. In practice, this capital capability is manifested in the form of an obligation to provide self-financing, which should be greater than the amount of credit requested from the bank.

\section{c. Capacity}

Capacity is the ability possessed by prospective customers to run their business in order to obtain the expected profit. The purpose of this assessment is to find out to what extent the prospective customer is able to repay or pay off his debts in a timely manner from the business he gets. The measurement of capacity can be carried out through the following approaches:

1) A historical approach, which is assessing past performance, does it show developments over time.

2) Financial approach, which is assessing the educational background of the board

3) Juridical approach, i.e. juridical, whether the prospective customer has the capacity to represent the business entity he represents to enter into a credit agreement with the bank.

4) Managerial approach, which assesses the extent to which the ability and skills of customers carry out management functions in leading the company. 
5) Technical approach, which is to assess the extent to which the ability of prospective customers to manage production factors such as labor, sources of raw materials, equipment, administration and finance, industrial relations to the ability to seize the market.

\section{d. Collateral}

Collateral is goods delivered by the customer as collateral for the credit received. The collateral must be assessed by the bank to determine the extent of the risk of the customer's financial obligations to the bank. In essence, the form of collateral is not only material but also intangible collateral such as personal guarantees (borgtocht), letters of guarantee, and letter of comfort, recommendations and avails.

\section{e. Condition of Economy}

Economy condition, namely political, social, economic, and cultural situations and conditions that influence the economic situation at a time that is likely to affect the smooth running of a prospective debtor company. To get a picture of this, research needs to be conducted on matters, among others:

1) Conjuncture state

2) Government Regulations

3) The situation, politics and the world economy

4) Other circumstances that affect marketing

\section{f. Constraint}

The constraint is a limitation and obstacle that does not allow a business to be carried out in a certain place, for example, the establishment of a gas station business in the vicinity of many welding shops or burning bricks. Of the six principles above, the most important need to get the attention of credit lending officials is character and collateral, and if this principle is not met, the other principles are meaningless. In other words, his application must be refused.

The application of the 6c's principle to lending is one form of application of the precautionary statement principle to financial institutions. According to SEBI No. 8/2006, the deed of agreement is final and binding so that no violations occur. Violations of the implementation of the provisions in the deed of the agreement are a breach of contract and can be prosecuted through a civil suit. ${ }^{19}$ Related to the application of the precautionary statement principle in banks or known as prudential banking in order to regulate the

\footnotetext{
${ }^{19}$ Lukmanul Hakim, “Analisis Alternatif Penyelesaian Sengketa Antara Pihak Nasabah Dengan Industri Jasa Keuangan Pada Era Otoritas Jasa Keuangan”, Keadilan Progresif 6, No. 2 (2015): 162.
} 
traffic of banking activities. ${ }^{20}$ So in giving credit to micro-businesses, it becomes one of the considerations in applying the precautionary principle so that their expectations in the legal aspect do not become a problem for the scope of micro-businesses because given that micro businesses have a high enough risk for indicators of banking institutions. ${ }^{21}$

The discussion above, it can be a conclusion that in the legal aspect through the development of micro-businesses, it is necessary to increase the legal aspects, especially in the application of the 6C's principle, especially in the financing aspect so that micro businesses do not experience any more difficulties in the scope of funding and in the guarantees outlined in the 6C's principle as a form of application of the precautionary principle.

\section{B. Conclusion}

Business development carried out by the government, and related institutions are to fulfil the elements of benefits for the welfare of the people, especially for micro businesses and the community, because the development of micro-businesses will affect economic development greatly affect the level of prosperity of a country. One of the roles of the Government in developing microbusiness is to develop quadruple helix as a concept of change and as one of the solutions to the problems of developing microbusinesses, especially in the lack of coaching and funding for microbusinesses. Microbusiness development from the legal aspect is to increase the capacity of a micro business in the legal sector, especially in the application of collateral so that micro businesses no longer have difficulties in terms of funding and do not make micro-businesses cause the impact of problem loans or even cause bad loans so that micro businesses do not become a cause The main contributors to non-performance loans.

\section{Recommendation}

It is hoped that the government will re-examine the relevant regulations and legislation in the implementation of supporting micro-businesses so that they do not overlap for micro-businesses in carrying out any business activities. It is expected that financial institutions, both banks and non-banks, can provide education to micro-businesses through the socialization of funding. Furthermore, micro-businesses can upgrade themselves from being business viable to be able to develop into banking feasible. So that what used

\footnotetext{
${ }^{20}$ Lukmanul Hakim dan Eka Travilta Oktaria, "Prinsip Kehati-Hatian Pada Lembaga Perbankan Dalam Pemberian Kredit”, KeadilanProgresif 9, No. September (2018): 166.

${ }^{21}$ Lukmanul Hakim, "The Alternative Model Settlement of Credit Problems in Banking Agencies", Fiat Justisia: Jurnal Ilmu Hukum 12, No. 2(2018): 143 -155, https://doi.org/10.25041/fiatjustisia.v12no2.1299.
} 
to be an informal micro-business with informal characteristics can be transformed into the formal sector through institutions.

\section{References}

Act Number 20 of 2008 Concerning Micro, Small and Medium Enterprises. Act Number 25 of 1992 Concerning Cooperatives.

Aldaba, R. M. SME.'Development: Narrowing the Development Gap in the ASEAN Economic Community."Philippine Journal of Development 39, No. 71(2012): 143-169.

Asheim, B. "Differentiated Knowledge Bases and Varieties of Regional Innovation Systems".The European Journal of Social Sciences 20, No. 3 (2007): 223-241, https://doi.org/10.1080/13511610701722846.

Budijanto, Danrivanto. Hukum Telekomunikasi, Penyiaran dan Teknologi Informasi: Regulasi dan Konvergensi. Bandung: Refika Aditama, 2010. Carayannis, E.G. \& Rakhmatullin, R. J. "The Quadruple/Quintuple Innovation Helixes and Smart Specialisation Strategies for Sustainable and Inclusive Growth in Europe and Beyond". Journal of Knowledge Economy 5, No. 2 (2014): 212-239, https://doi.org/10.1007/s13132014-0185-8.

Edquist, C. \& Hommen, L. "Systems of innovation: Theory and Policy for the Demand Side". Technology in Society21 (1999): 63-79.

Fajar, Mukti., Yulianto Achmad. Dualisme Penelitian Hukum Normatif dan Empiris. Yogyakarta: Pustaka Pelajar, 2010.

Hakim, Lukmanul. "Analisis Alternatif Penyelesaian Sengketa Antara Pihak Nasabah Dengan Industri Jasa Keuangan Pada Era Otoritas Jasa Keuangan”. Keadilan Progresif 6, No. 2 (2015): 162

Hakim, Lukmanul. "The Alternative Model Settlement of Credit Problems In Banking Agencies", Fiat Justisia: Jurnal Ilmu Hukum12, No. 2 (2018):143 -155, https://doi.org/10.25041/fiatjustisia.v12no2.1299.

Hakim, Lukmanul. Eka Travilta Oktaria. "Prinsip Kehati-Hatian Pada Lembaga Perbankan dalam Pemberian Kredit." Keadilan Progresif 9 No. September (2018): 166.

IDKR, Ardiana. Brahmayanti IA, Subaedi. "Kompetensi SDM UKM dan pengaruhnya terhadap kinerja UKM di Surabaya". Jurnal Manajemen dan Kewirausahaan 12, 1 (2010): 42-55.

Indonesian Bank Circular No. 8/14/DPNP 2006 about Banking Mediation (SEBI No. 8/2006).

Kiran V, Majumdar M, Kishore K. "Innovative Marketing Strategies for Micro, Small and Medium Enterprises". Interdisciplinary Journal ofContemporary Research in Business 4, 2 (2012): 1059-1066. 
Lundvall, B. A. National Systems of Innovation. Towards a Theory of Innovation and Interactive Learning. London: Pinter Publishers, 1992. Moulaert, F., Sekia, F. "Territorial Innovation Models: A Critical Survey". Regional Studies 37, No. 3 (2002): 289302, https://doi.org/10.1080/0034340032000065442.

Munizu, M. "Pengaruh Faktor-Faktor Eksternal dan Internal Terhadap Kinerja Usaha Mikro dan Kecil (UMK) di Sulawesi Selatan". Jurnal Manajemendan Kewirausahaan 12, 1 (2010): 33-41.

Murwadji, Tarsisius. "Edukasi dan Penyehatan Koperasi Melalui Linkage Program Perbankan". PADJADJARAN Jurnal Ilmu Hukum 4, No. 3 (2017), https://doi.org/10.22304/pjih.v4n3.a2.

Piirainen, T. \& Koski, P. "Integrating Workplace Development Policy and Innovation Policy a Challenging Task Experiences from the Finnish Workplace Development Program" in Fricke, Werner and Totterdill, Peter (eds) Action Research in Workplace Innovation and Regional Development (Amsterdam: John Benjamins,2004), 313-331.

PSIK, Tim Peneliti. Negara kesejahteraan dan globalisasi, Pusat Studi Islam dan Kenegaraan (PSIK).Jakarta: Universitas Paramadina, 2007.

Risnain, Muh. Aspek-Aspek Hukum Peningkatan Daya Saing Industri Dalam Perdagangan Bebas. Bandung: Keni Media, 2015.

Soekanto, Soerjono. Beberapa Permasalahan Hukum Dalam Kerangka Pembangunan di Indonesia. Jakarta: Yayasan Penerbit Universitas Indonesia, 1975.

Spicker, Paul.Social Policy: Themes and Approaches. London: Prentiece Hall, 1995.

Susila, Ihwan. “Analisis Efisiensi UMKM”. Jurnal Ekonomi Pembangunan 8, No. 2 (2007).

Tambunan, Tulus. Usaha Mikro Kecil dan Menengah di Indonesia (Isu-Isu Penting). Bogor: Ghalia Indonesia, 2017.

Thalassinos, I. E., D.T. Stamatopoulos, and E. P. Thalassinos.The European Sovereign Debt Crisis and the Role of Credit Swaps. Chapter book W. T. Ziemba and A.G. Malliaris, "The WSPC Handbook of Futures Markets" (eds), in memory of Late Milton Miller (Nobel 1990) World Scientific Handbook in Financial Economic Series 5, No. 20 (2015): 605-639, doi:10.1142/9789814566926_0020.

Thalassinos, I.E. and Liapis, K. Segmental Financial Reporting and the Internationalization of the Banking Sector. Chapter Book Risk Management: Strategies for Economic Development and Challenges in the Financial System, 2014.

The 1945 constitution of Indonesia.

Wise, E. \& Høgenhaven, C. User-Driven Innovation. Contex and Cases in the Nordic Region. Nordic Innovation Centre, 2008. 
Wuryandari, Ganewati. et al. Politik luar negeri Indonesia: Di Tengah Pusaran Politik Domestik (Yogyakarta: Pustaka Pelajar, 2008). 